\title{
DIAGENESIS OF THE CENTRAL BASQUE- CANTABRIAN BASIN (IBERIAN PENINSULA) BASED ON ILLITE-SMECTITE DISTRIBUTION
}

\author{
J. ARÓSTEGUi, M.C. ZULUAGA, F. VELASCO, \\ M. ORTEGA-HUERTAS* AND F. NIETO*
}

\begin{abstract}
Departamento de Mineralogia y Petrologia, Universidad del Pais Vasco, and *Departamento de Mineralogia y Petrología, Instituto Andaluz de Geologia Mediterránea. Universidad de Granada, Spain
\end{abstract}

(Received 24 September 1990; revised 20 February 1991)

\begin{abstract}
A BSTR ACT : X-ray diffraction was used to analyse the distribution of clay minerals in the $<2 \mu \mathrm{m}$ fraction of the lutitic and marly facies from the centre of the Basque-Cantabrian Basin (Basque Arc). where the sedimentary section is 2000 to $10.000 \mathrm{~m}$ thick. Most of the deposits were laid down during the Cretaceous and Paleogene and were related to the opening and closing of the Bay of Biscay. The most noteworthy variations are in kaolinite, smectite and mixed-layered $(R=0, R=1$ and $R \geq 3$ ) illite-smectite, which can be ascribed both to provenance and to diagenesis. A general diminution in expandability is related to the gradual transformation of smectite to illite from south to north, and with depth. Temperature, residence time and chemical activity during diagenesis are the factors that had greatest influence on the changes in the original mineral assemblages inherited from the source area. On the basis of the clay minerals and the Kübler index, a general scheme is proposed for the diagenetic evolution of the area from the initial stages to anchimetamorphism.
\end{abstract}

The Basque-Cantabrian Basin has undergone a long depositional history, from the Permian-Triassic to the present. Deposits accumulated in different sectors of the basin from the Lower Cretaceous to the Middle Eocene, with thickness ranging from more than $10,000 \mathrm{~m}$ in the north and centre, to approximately $2000 \mathrm{~m}$ at the southernmost extreme of the basin. This indicates considerable differences in the subsidence and sedimentation rates, related to the opening and closing of the Bay of Biscay within the overall geotectonic evolution of the central Atlantic Ocean.

Since 1940 many oil companies have explored the area, generally with little success, but recently the discovery of gas and condensates offshore in the Gaviota field has led to further exploration both at sea and on land. Nevertheless, despite the considerable number of boreholes $\left(80 / 10,000 \mathrm{~km}^{2}\right)$, there is still very little information regarding the degree of diagenesis throughout the basin.

In this paper we present the first data on the distribution of clay minerals from a series of geological sections throughout the central region of the basin (Basque Arc). Emphasis is placed on the distribution and type of illite-smectite (I-S) mixed-layered phases, as this group of minerals has been frequently used in other basins as an indicator of the temperatures reached in the deposits, the transformation of smectite towards illite being highly temperature dependent (Jennings \& Thompson, 1986; Pearson \& Small, 1988). This transformation has also been related to the generation of hydrocarbons (Bruce, 1984; Burtner \& Warner, 1986; Scotchman, 1987). However, the use of this criterion requires the existence of an original phase containing a greater proportion of smectite layers than those 
remaining at present. Furthermore, as far as the mechanism of illitization is concerned, it is important to bear in mind that various factors are involved in the reaction (Scotchman. 1987) and it is therefore difficult to make absolute comparisons between basins and even between different sectors of the same basin.

\section{GEOLOGICAL CONTEXT}

The Basque-Cantabrian Basin, between the Palaeozoic massifs of Cinco Villas to the east and Asturiano to the west, forms part of the most westerly domain of the Pyrenean chain (Fig. 1). The study area comprises a N-S cross-section of the central region, or Basque Arc Domain (Rat, 1959; Feuillée \& Rat, 1971). Its geological history has yet to be fully understood, but is clearly connected with the complicated opening and closure of the Bay of Biscay (Boillot \& Malod, 1988).

The history before the uppermost Jurassic-lowermost Cretaceous is poorly documented. During the Lower Cretaceous in the central sector there are clayey-lacustrine deposits with intercalated sandy delta lobes (Wealden Complex) that may be up to $2000 \mathrm{~m}$ thick. According to drilling data these deposits give way laterally southwards to thin fluviatiledelta facies (Ramírez del Pozo, 1987). To the north the lithologies include more carbonates and are $\sim 300 \mathrm{~m}$ thick.

An overall N-S transgression from the Aptian gave rise to the development of rudist carbonate platforms, among which there are both vertical and horizontal detrital deposits of varying thicknesses (Urgonian complex). Detrital influx increased considerably in the central and southern sectors during the Upper Albian-Lower Cenomanian, with deposition of proximal platform facies to the south, and in the centre a thick sandy delta assemblage with lutitic intercalations (supra-Urgonian complex). This period is represented in the north by talus-slope turbiditic facies.
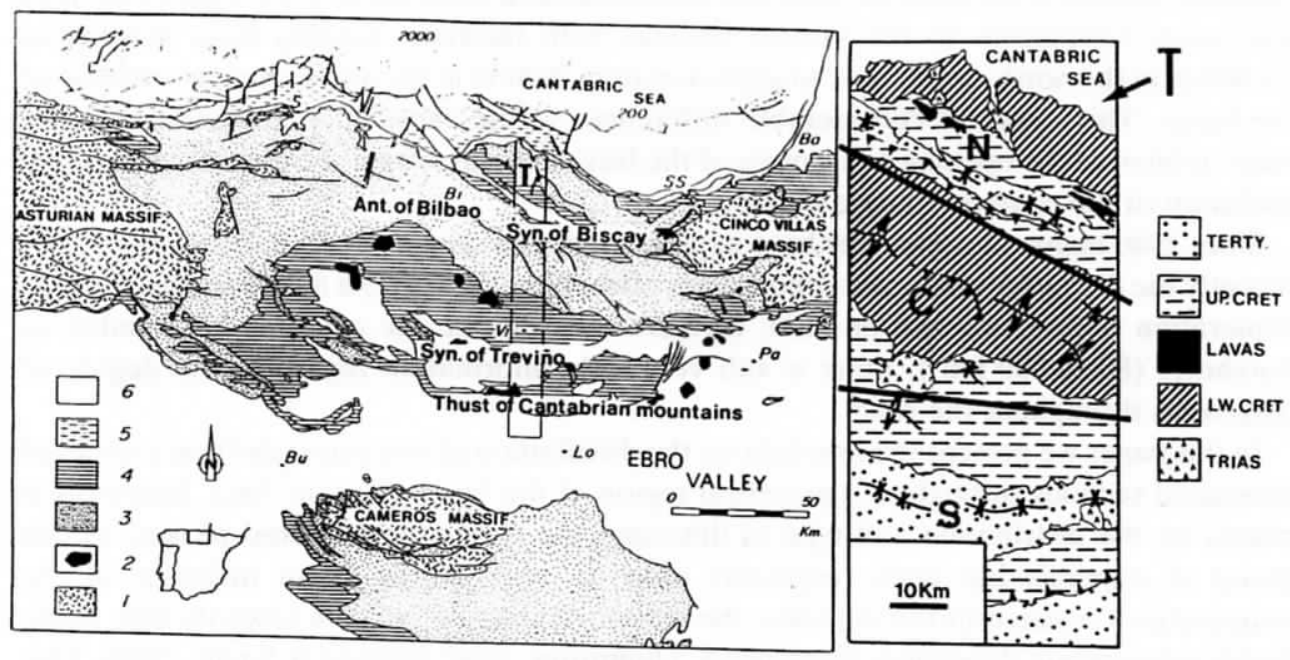

FIG. 1. Geology of the Basque-Cantabrian Basin and the region studied (T). N, C, S correspond to the northern, central and southern sectors, respectively. (1) Palaeozoic; (2) diapiric Triassic: (3) Lower Cretaceous (impossible to map in the southern sector); (4) Upper Cretaceous: (5) unspecified Cretaceous; (6) Tertiary. 
Throughout the Upper Cretaceous and Paleogene the lithology of the deposits laid down in this area is very different from that of the underlying ones. They are mainly carbonates with the shallower facies lying to the south. In the northern sector. accompanying the carbonate lithologies, there are some flyschoid siliciclastic episodes (Mathey. 1987) and intercalated alkaline volcanic flows up to the Lower Santonian. The stratigraphic continuity pinches out laterally during the Upper Cretaceous in the region of the Bilbao anticline and during the Tertiary in the whole of the central sector (Fig. 1), partly because of erosion.

Tilting of blocks at great depth during the Oligocene-Miocene gave rise to a sedimentary trench in the southern sector, the extension of which corresponded to the modern Neogene continental facies collected in the Treviño syncline (Fig. 1).

A series of palaeogeographic realms were shaped by the depositional history. These realms may have been controlled by deep NW-SE trending, as the tectonic faults coincide in general with the boundaries between the sectors being described, and were regionally fractured in a NE-SW direction in the form of domes and basins. Although directions of sediment supply have not been conclusively established, they would appear to have been from the south and southwest in the southern and central sectors, and from the north and southeast in the northern sector. This implies the existence of several different source areas for the whole of the sedimentary basin (Amiot et al., 1982).

\section{MATERIALS AND METHODS}

In accordance with the geological characteristics, the study area was divided into three sectors: northern, central and southern (Fig. 1). A total of 153 samples, uniformly distributed among the sectors, were collected from a series of sections across the directions of the principal geological structures. These samples included representative, unaltered pelitic rocks corresponding mainly to lutites and marls, with occasional fine sandstones from the Tertiary in the southern sector.

The samples were washed and crushed with a jaw crusher. Non-oriented powder samples were prepared for bulk mineralogical analysis by X-ray diffraction (XRD), and semiquantitative estimations of concentrations were made using Schultz's method (1964). The overall mineralogical composition is illustrated in Fig. 2. One noteworthy feature is the general lack of carbonates in the Lower Cretaceous compared to their presence in the rest of the samples.

The $<2 \mu \mathrm{m}$ fraction was separated by centrifugation and homo-ionized with $2 \mathrm{~N} \mathrm{CaCl}_{2}$. After several further washings, four types of oriented aggregates were prepared: air dried, glycolated, treated with dimethyl sulphoxide at $70^{\circ} \mathrm{C}$, and heated to $550^{\circ} \mathrm{C}$ for one hour. The relative concentrations of clay minerals in the $<2 \mu \mathrm{m}$ fraction were estimated according to the methods of Biscaye (1965) and Schultz (1964).

I-S mixed-layers were classified as random $(\mathrm{R}=0)$ and ordered $(\mathrm{R}=1$ and $\mathrm{R} \geq 3)$ (Reynolds, 1980). Examples of each type are shown in Fig. 3. Within the $\mathrm{R}=0$ random samples, two types of XRD profiles could be discerned: in the glycolated sample the first profile showed a peak at $17 \AA$ ( $R=0$ in the strict sense), whereas in the second profile the peak was reduced to a small shoulder $(\mathrm{R}=0-1$ in the sense of Bethke \& Altaner, 1986). The expandability was determined by the method of Inoue et al. (1989), giving results of $>50 \%$ and $40-50 \%$ expandable layers, respectively. The $R=1$ and $R \geq 3$ profiles (Fig. 3) contained $15-40 \%$ and $\leq 15 \%$ expandable layers, respectively, according to the methods of Reynolds \& Hower (1970) and Srodon (1984). Whether mixed-layered phases really occur 

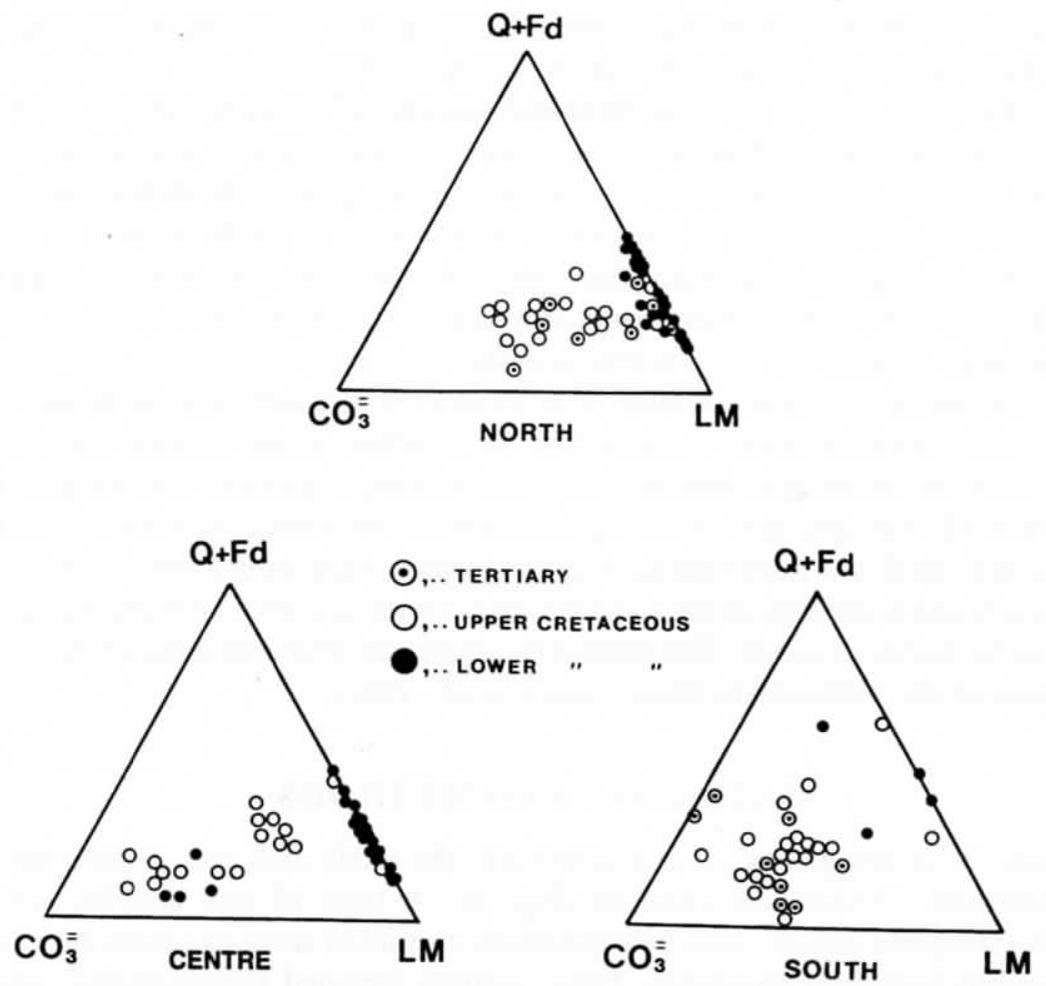

FiG. 2. Diagrams of the proportions of minerals of bulk samples from each sector; $Q+F d=$ quartz + feldspars, $\mathrm{CO}_{3}=$ carbonates, $\mathrm{LM}=$ phyllosilicates.

during diagenesis is still a controversial question. In this study, therefore, we use Reynolds' term "mixed layer" as a useful term of reference with no attempt to define the physical reality of the $\mathrm{R}$ parameter.

We measured the Kübler index (1968) in all samples as recommended by the IGCP 294 IC Working Group (Kisch, 1990). The anchizone limits of our diffractometer obtained from the standard samples analysed in Prof. Kübler's Neuchâtel Laboratory are 0.52 and $0 \cdot 31^{\circ} 2 \theta$.

\section{MINERAL ASSEMBLAGES}

The greatest differences in the clay minerals of the $<2 \mu \mathrm{m}$ fraction are to be found when comparing the northern and central sectors with the southern one, within which the minerals are much more varied (Fig. 4). Detrital mica, taken as being the portion of the $10 \AA$ peak that does not change after treatment with ethylene glycol, is the major mineral in almost all the samples. Chlorite is in general scarcer, with a fairly uniform content throughout the samples. The most notable differences occur in the distribution of I-S and kaolinite. The proportion of kaolinite diminishes downwards stratigraphically, and northwards laterally in all three chronological reference periods (Fig. 4). The highest kaolinite content was found in the Tertiary of the southern sector, particulary the Paleocene, where the facies are transitional or clearly continental. In the northern sector, 


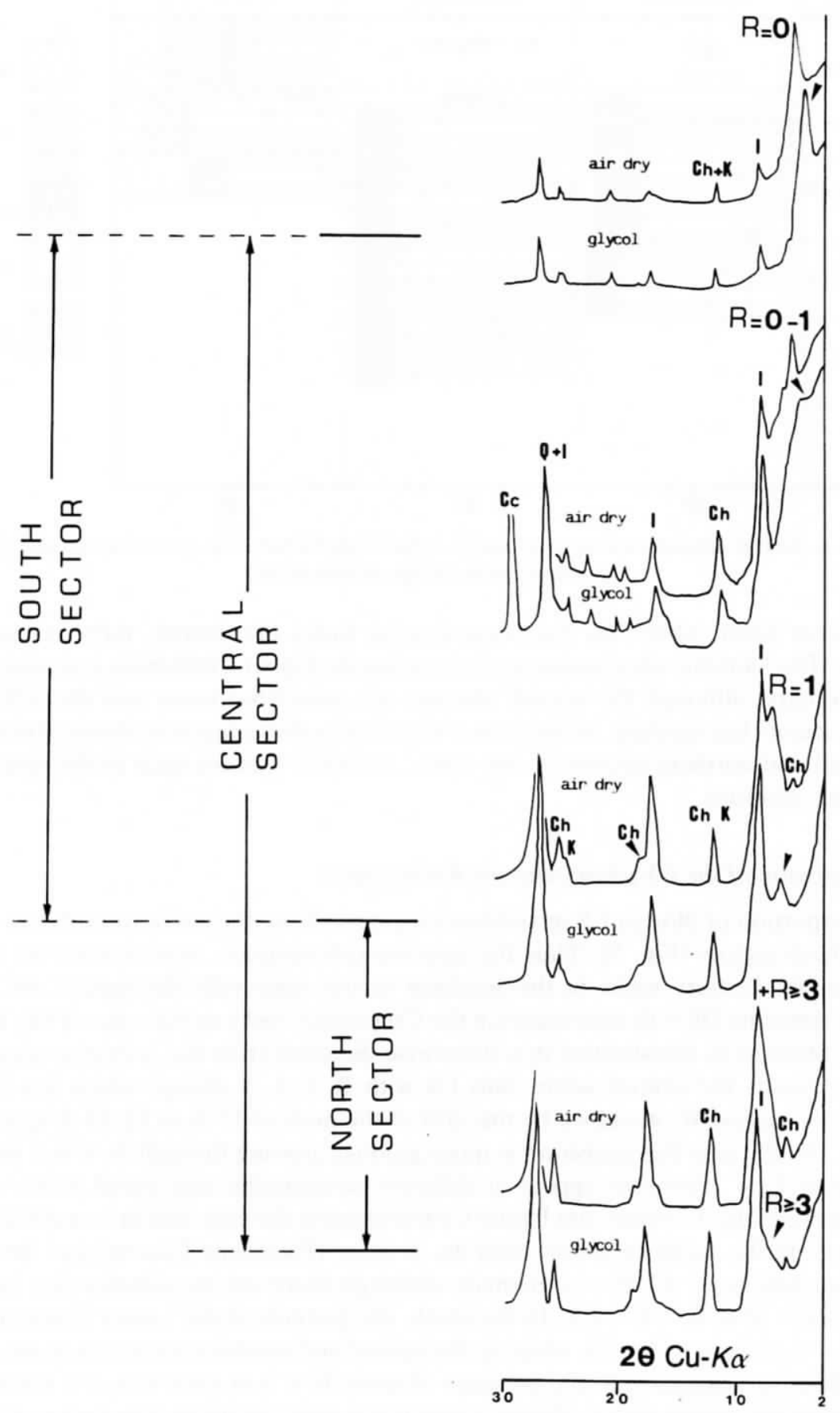

FIG. 3. XRD patterns of the $<2 \mu \mathrm{m}$ fractions and their chronostratigraphic evolution in each sector. All the samples are $\mathrm{Ca}$-saturated. $\mathrm{Ch}=$ chlorite: $\mathrm{K}=$ kaolinite: $\mathrm{I}=$ illite: $\mathrm{R}=0, \mathrm{R}=1$ and $\mathrm{R}=\geq 3$ are I-S mixed-layers (see text for details). 


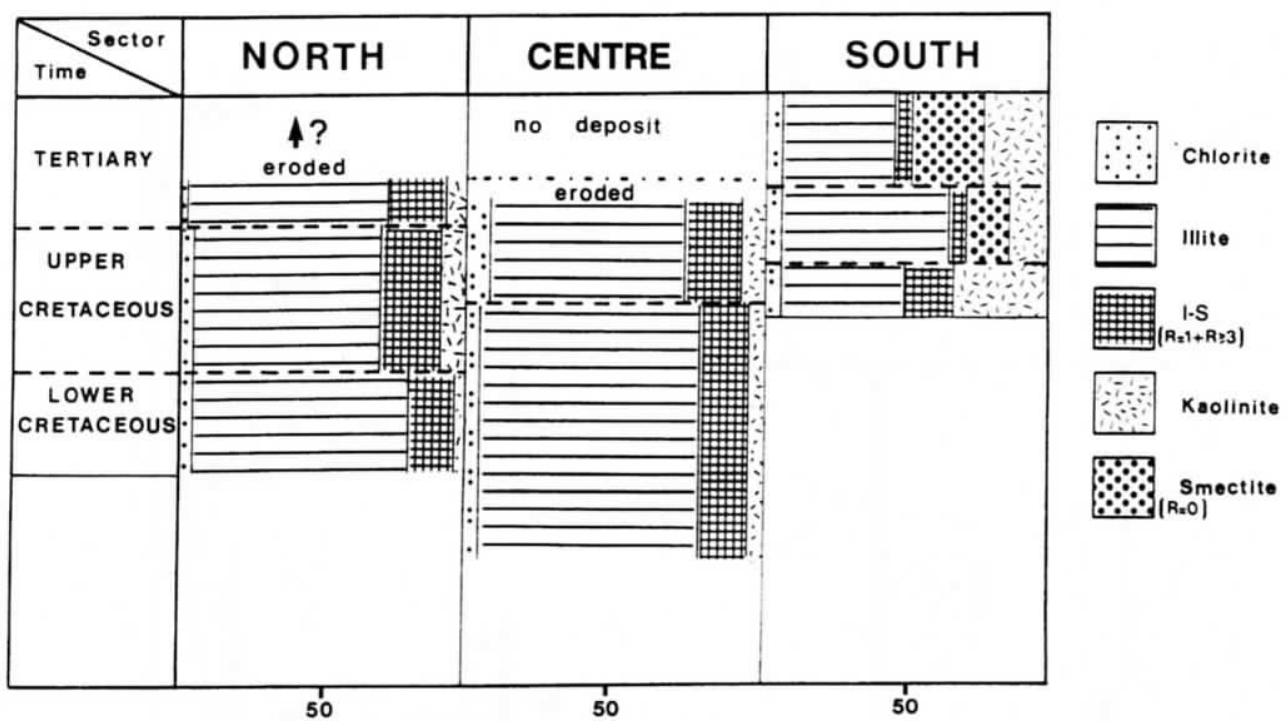

FIG. 4. Average distribution of the clay minerals in the $<2 \mu \mathrm{m}$ fraction. The dashed lines indicate the boundaries between ages in each sector.

on the other hand, where the Paleocene-Eocene facies are deeper, there is much less kaolinite. The kaolinite distribution pattern during the Upper Cretaceous is similar to that of the Tertiary, although the overall amounts are somewhat lower and the differences between sectors less marked. In the Lower Cretaceous this mineral is almost absent from the central and northern sectors; in the south, kaolinite was detected in the rare Lower Cretaceous outcrops.

\section{The distribution of the I-S phases and the Kübler index}

The proportion of illite in I-S mixed-layer increases from the south towards the central and northern sectors (Fig. 5). Thus the smectite-rich samples, characterized by $\mathrm{R}=0$, appear in the Tertiary rocks in the southern sector, especially throughout the Lower Miocene. Smectite $(\mathrm{R}=0)$ also occurs in the Cretaceous rocks on the edge of the Treviño syncline. Smectite is transformed in a transverse direction from the northern edge of the syncline towards the central sector into I-S with $R=1$, a change which has become complete by section W, as shown by the shift of the peak at $17 \AA$ to $12-13 \AA$ (glycolated samples). To the east this transition is more gradual, passing through $R=0-1$ patterns; well-defined $R=1$ patterns appear at different stratigraphic and burial levels in both areas-between the Turonian and Upper Cenomanian in the east, and in Lower Coniacian in the west. In the northern sector, both the Tertiary (Paleocene-Eocene) and the Upper Cretaceous belong to the $R=1$ domain, although there are no samples rich in either smectite $(\mathrm{R}=0)$ or $\mathrm{R}=0-1 \mathrm{I}-\mathrm{S}$. In the south, the patterns of the Lower Cretaceous are either $\mathrm{R}=1$ or close to $\mathrm{R} \geq 3$, while in the central and northern sectors they are mainly $R \geq 3$. However, attention to the presence of some $R=1$ or even $R=0-1$ I-S in some samples from the central sector, always in association with calcareous lithologies, should be noted.

The Kübler index values are lowest in samples with high proportions of smectite $(R=0)$ 


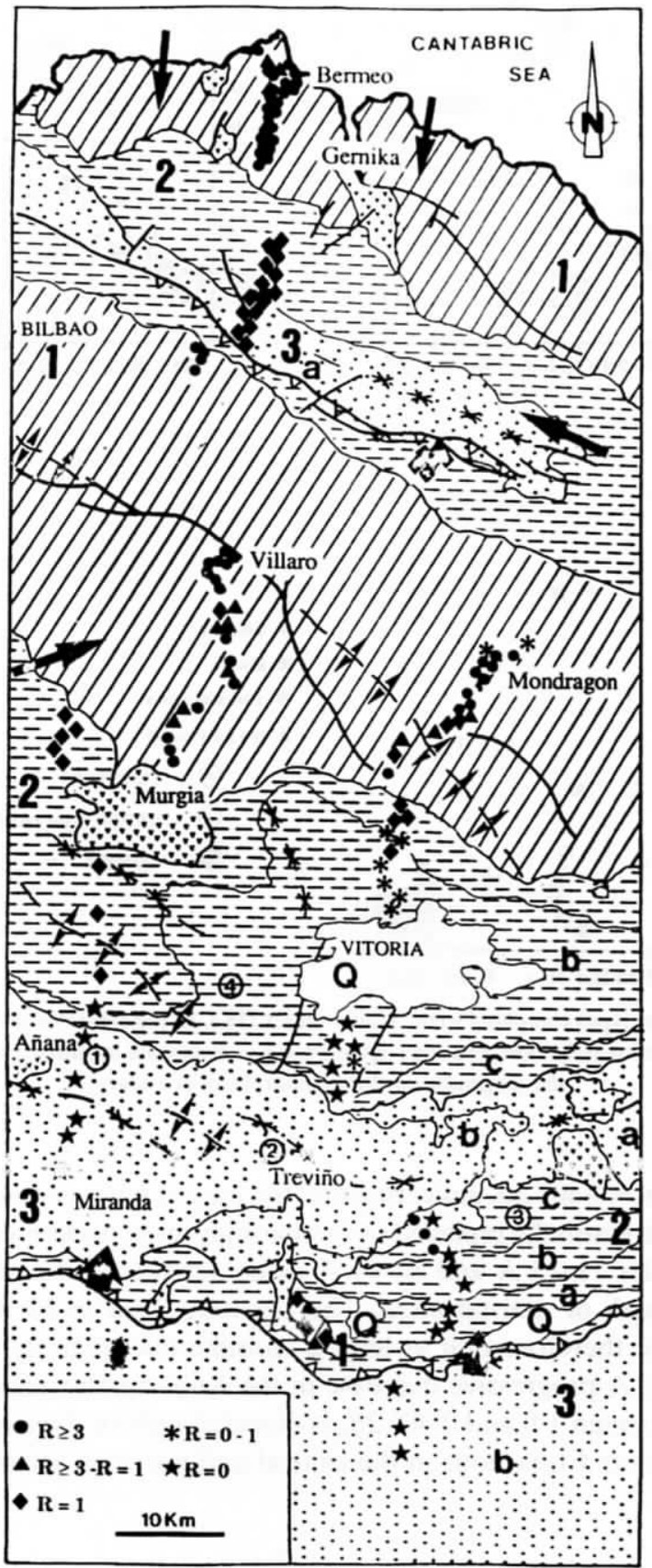

Fig. 5. Distribution map of the I-S types in the central sector of the Basque-Cantabrian Basin. (1) Lower Cretaceous; (2) Upper Cretaceous, 2a Middle Cenomanian-Lower Coniacian, 2b Coniacian-Campanian, 2c Upper Campanian-Maestrichtian; (3) Tertiary, 3a Paleogene, $3 \mathrm{~b}$ Neogene; Q Quaternary. (The arrows indicate the direction of sources in each age and sector, and the numbers within circles indicate borehole sites). 

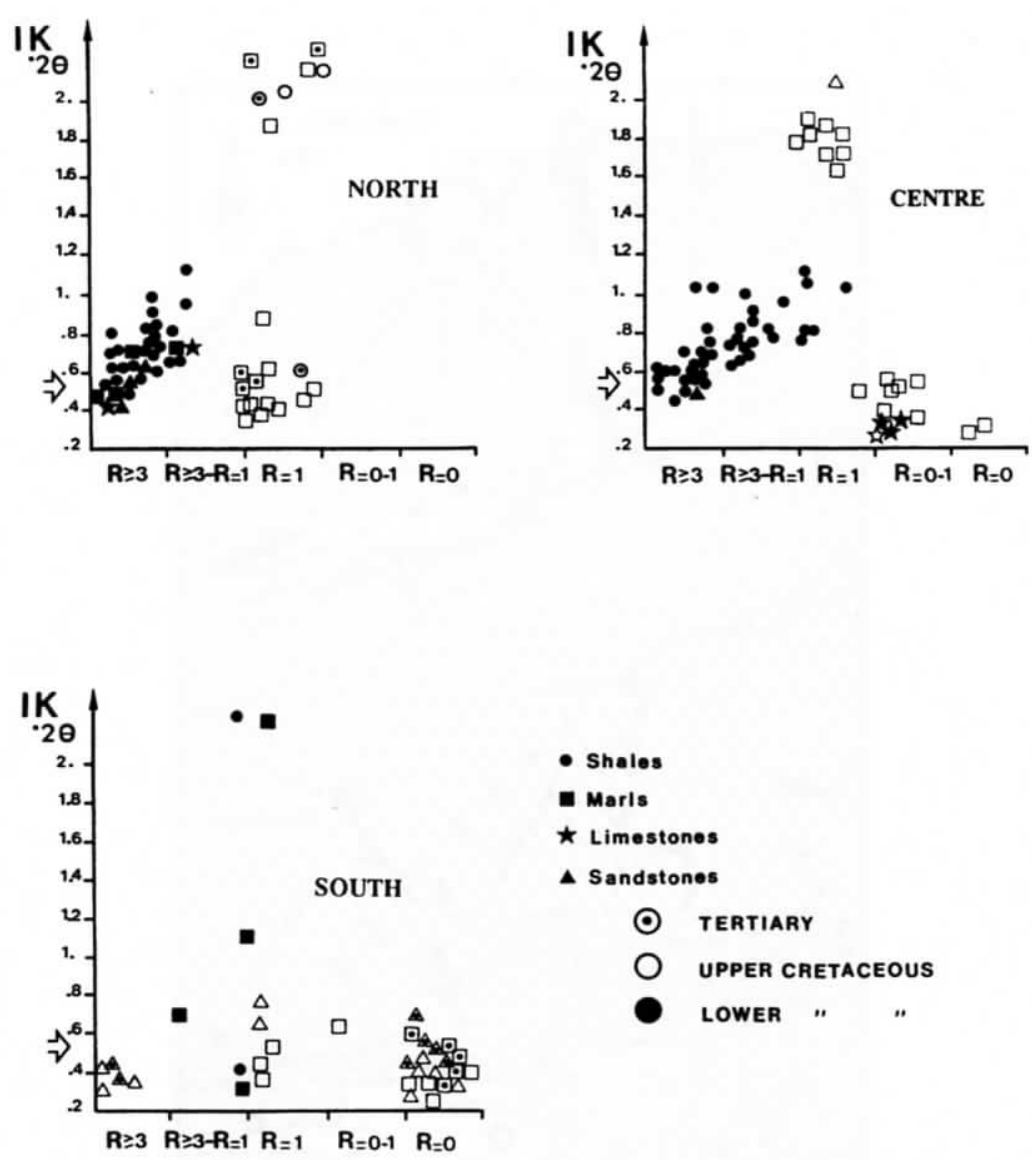

FIG. 6. Mixed-layer types compared to the Kübler index (IK). In the central sector the samples from the Upper Cretaceous at the northern edge of the Treviño syncline are included. (The arrow indicates the diagenesis-anchimetamorphism boundary).

(Fig. 6) and are often $<0 \cdot 40^{\circ} 2 \theta$, indicating that the mica is fairly crystalline. As the discrete smectite domains are gradually replaced by increasingly large packets of neoformed illite, in the untreated samples $11-13 \AA$ and $10-11 \AA$ peaks (characteristic of $\mathrm{R}=1$ and $\mathrm{R} \geq 3$ ) overlap the $10 \AA$ peak of detrital mica. The resulting peak at $10 \AA$ then progressively narrows. We believe therefore that at least a considerable quantity of the illite in these samples is inherited. A progressive decrease in the Kübler index concomitant with depth (values generally between 1.0 and $0.40^{\circ} 2 \theta$ ) is detected only in the samples with an $R \geq 3$ pattern from the Lower Cretaceous in the central and northern sectors (Fig. 6).

\section{DISCUSSION}

Detrital mica and minor chlorite are constantly present in the samples as inherited material from source rocks. The kaolinite and smectite $(R=0)$ are often considered as being 
inherited from soils developed in the source area in the semi-arid climate that prevailed in this peri-Atlantic domain during the Cretaceous and most of the Tertiary (Chamley, 1979; Miller et al., 1987). Similarly, the abundance of kaolinite in the southern sector indicates relative proximity to emerged areas (Singer, 1984; Chamley, 1989) (Fig. 4). This is particularly evident during the Paleocene which is represented by continental facies laid down under a regressive regime (Ramírez del Pozo, 1973) when the kaolinite content was at its highest. Other factors, such as possible variations in seasonal changes and intensity of drainage in the source area, may also control the inverse proportions of kaolinite and smectite in the southern sector.

The absence of kaolinite in the samples from the central and northern sectors during the Lower Cretaceous is almost certainly due to diagenesis, and the climatic conditions during this period allowed the development of red, kaolinite-rich, continental materials (Rat, 1959) which are clearly evident in the south where the Lower Cretaceous is buried much less deeply.

Similarly, the overall diminution in the discrete smectite content of the rocks and smectite layers of I-S from south to north can be ascribed to an increase in the degree of diagenesis. XRD profiles have been obtained from the $<2 \mu \mathrm{m}$ fraction that correspond to a progressive change form $R=0$ to $R \geq 3$, which is related to an illitization process. High-resolution transmission electron microscopy studies carried out by Ahn \& Peacor (1986) on the samples of Hower et al. (1976), with XRD patterns corresponding to $\mathrm{R}=0$ and $\mathrm{R}=1$, indicated that the transformation from smectite to illite takes place via the build- up of progressively larger illite packets (50-100 $\AA$ and $>100 \AA$, respectively). The complete absence of smectite domains corresponds to $\mathrm{R} \geq 3 \mathrm{XRD}$ profiles (sample 15,558 $\mathrm{ft}$, Brazoria County, in Freed \& Peacor, 1989). The factors most frequently referred to in the literature as playing an important part in this transformation are the structure and composition of the original smectite, the chemical activity of the diagenetic medium, temperature, residence time and permeability (Ahn \& Peacor, 1986; Inoue et al., 1987, 1989; Eberl \& Srodon, 1988).

A representation of the stratigraphic sections in each of the three sectors studies (one to the east and another to the west in the central sector) is shown in Fig. 7. In all of these sections burial depth is indicated, as reconstructed from a comparision of the type and distribution of the facies based on both surface and borehole data (IGME, 1987) for the first burial cycle, which was diachronic throughout the region. A second cycle, particularly affecting most of the Upper Cretaceous on the northern edge of the syncline, took place during the Neogene in the southern sector (Treviño syncline), with no apparent influence on the diagenesis.

In all of the sections, the decrease in smectite, as shown by the transition from $R=0$ to $R=1$ and $R \geq 3$, coincides with an increase in burial depth, indicating that burial temperature would seem to control the transformation to some extent.

I-S with $\mathrm{R}=1$ occurs at different depths and bears no relationship to the age of the rocks in any of the sections studied. It occurs deeper in proportion to the thickness of the materials corresponding to the first burial cycle (originally very reduced to the west due to the uplift of the Murgia diapir) which emerged during the upper Campanian (Stackelberg, 1960). Thus, in the Upper Cretaceous in the central sector, $\mathrm{I}-\mathrm{S}$ with $\mathrm{R}=1$ occurs at $2600 \mathrm{~m}$ in the west, whereas in the east it is first encounteed at $4100 \mathrm{~m}$. Although it is impossible to obtain stratigraphically continuous samples in the southern sector, it can be inferred that $\mathrm{I}-\mathrm{S}$ with $\mathrm{R}=1$ occurs at $\sim 2000 \mathrm{~m}$. The occurrence of $\mathrm{I}-\mathrm{S}$ with $\mathrm{R}=1$ can be 

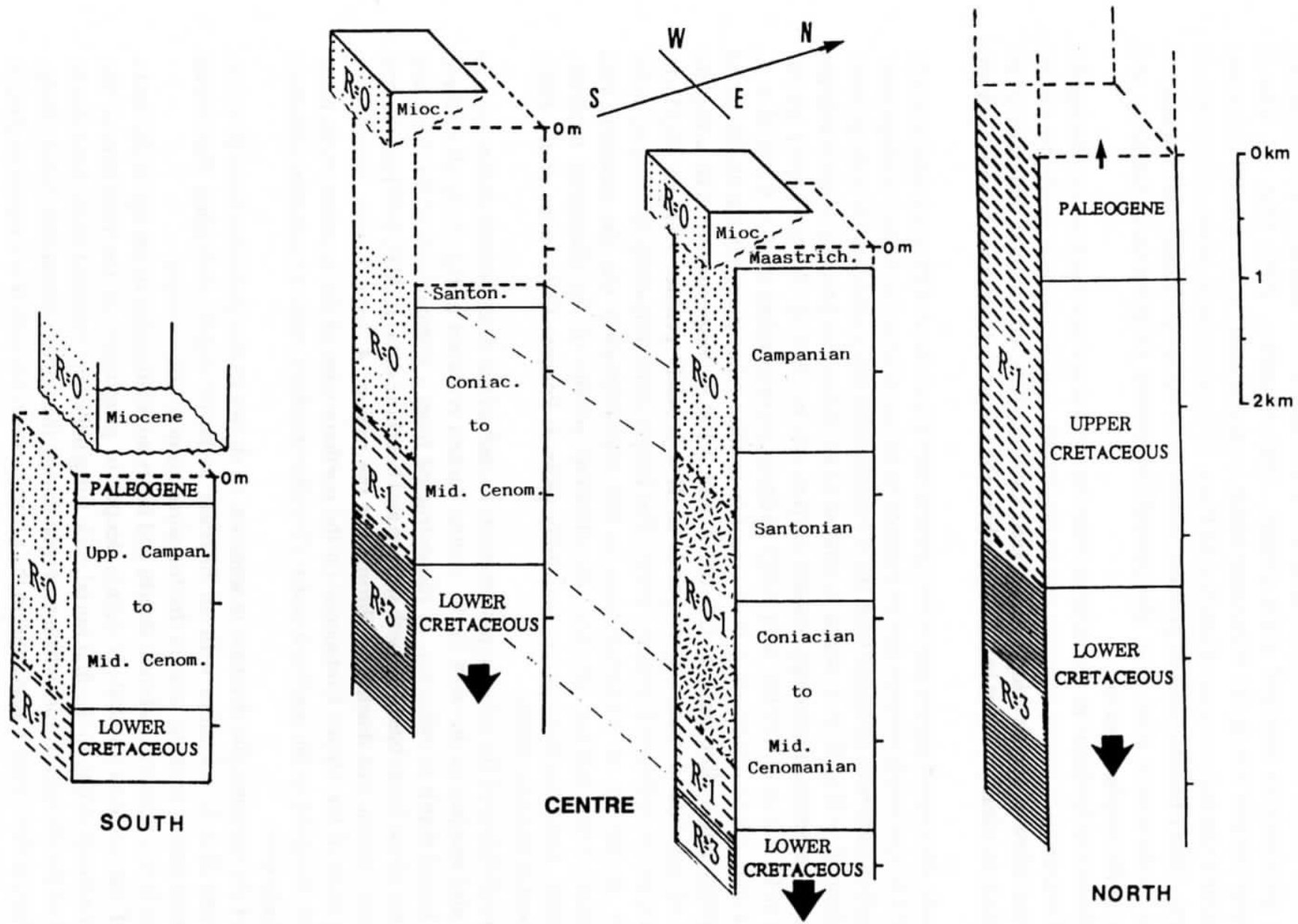

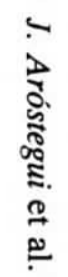

FIG. 7. Reconstructed stratigraphic sections indicating the mixed-layer type through time. In the sections belonging to the central sector, the northern edge of the Treviño syncline has been included. 
calculated, from a geothermal gradient of $30^{\circ} \mathrm{C} / \mathrm{km}$, to have taken place at approximately 95 and $140^{\circ} \mathrm{C}$ in the western and eastern sections, respectively; in the south the temperature would have been $\sim 75^{\circ} \mathrm{C}$. Various temperatures have been proposed for the $\mathrm{R}=0$ to $\mathrm{R}=1$ transformation (Heling, 1974; Hower et al., 1976: Bruce, 1984: Pearson \& Small, 1988), which cover the range we have obtained, and are explained in terms of some of the other factors mentioned above.

By comparing the relative thicknesses of the statigraphic sections in the southern and central sectors, it can be seen that the causes of subsidence and sedimentation must have been quite different, and consequently the residence time in the same temperature ranges was also different, as the geothermal gradient in both zones was similar. This it would seem reasonable to conclude that, apart from temperature, residence time is also an important factor in the $\mathrm{R}=0$ to $\mathrm{R}=1$ transition process (Bethke \& Altaner, 1986).

Erosion after the uplift of the basin and the lack of comparable stratigraphic and sedimentological records in adjacent zones make it impossible to attempt a reconstruction of burial history in the northern sector. The Paleocene-Middle Eocene and Upper Cretaceous sediments in this sector contain $R=1 \mathrm{I}-\mathrm{S}$ instead of smectite $\mathrm{R}=0$. The fact that the diagenetic conversion of smectite $(R=0)$ to $R=1 \mathrm{I}-\mathrm{S}$ is complete would seem to be a result of the different rate of transition in the I-S sequence, which is related to factors mentioned above. Alternative explanations, such as retrograde hydrothermal alteration of mica as described by Jiang et al. (1990), or the existence of shales with R = $1 \mathrm{I}-\mathrm{S}$ in the source area, are less probable and have not been demonstrasted for the area studied.

The change with depth of the XRD profiles, corresponding to a transition from $R=1$ to $\mathrm{R} \geq 3$, marks the complete absence of discrete smectite domains. This can be seen in both the central and northern zones and coincides with the Lower-Upper Cretaceous boundary (Figs. 5 and 7). This boundary is also lithologically very clear, with the detrital-terrigenous materials being superseded by marls.

Abundant smectite domains are now present only in the Lower Cretaceous of the southern sector. However, their probable existence in the original sediments throughout all of the area examined indicates the importance of the influence of burial temperature in the transformation of smectite. The fact that $\mathrm{R} \geq 3 \mathrm{I}-\mathrm{S}$ begins to develop at the same time as detrital-terrigenous sedimentation suggests that lithological characteristics such as composition and permeability may be important factors in the transformation of smectite, in agreement with the opinions expressed by Freed \& Peacor (1989).

Once the $R \geq 3$ state had been reached, diagenesis may have continued with progressive diminution of the Kübler index with depth. Thus, in the materials at the bottom of the Lower Cretaceous in the central and nothern sectors, values of $2 \theta<0.52^{\circ}$ are to be found, as consistent with, but no higher than, anchimetamorphic grades.

Figure 8 summarizes the diagenetic scheme for this region based on the distribution of clay minerals and the Kübler index (KI) values. The evolution of this parameter is characteristic of a region where an important quantity of detrital mica coexists with the neoformed I-S. In the zone of shallow diagenesis, I-S with $R=0$ and $R=0-1$ do not overlap the peak of detrital mica, and the $\mathrm{KI}$ is that of highly crystalline mica (Fig. 6). The development of $\mathrm{R}=1 \mathrm{I}-\mathrm{S}$ in the middle diagenesis zone causes a significant widening of $\mathrm{KI}\left(1 \cdot 5^{\circ} 2 \theta\right)$, which varies according to the I-S detrital mica ratio. The gradual change of $\mathrm{R}=1$ to $\mathrm{R} \geq 3 \mathrm{I}-\mathrm{S}$ together with a progressive enrichment in illite in the zones of deep diagenesis and anchimetamorphism produces a gradual decrease in the KI, coinciding with the approach of the I-S peak to the mica peak. 


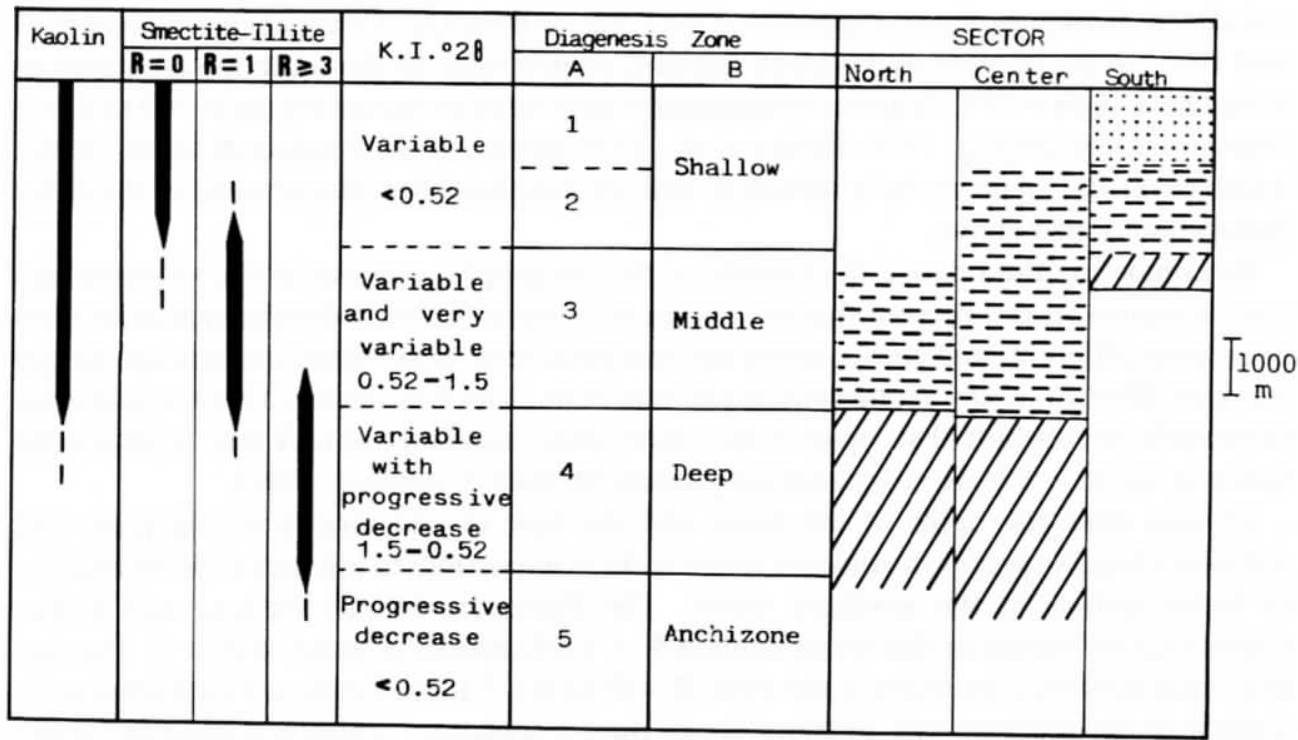

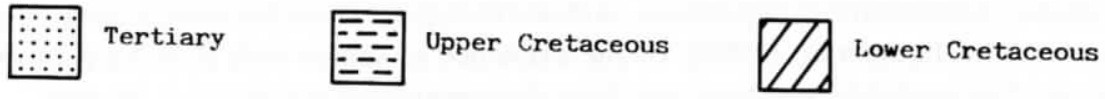

Fig. 8. Diagenetic zoning of the central region of the Basque-Cantabrian Basin, based on the distribution of the clay minerals and the Kübler index. A: Diagenesis zones based on Kübler $e t$ al., 1979, Table 3 (in Kisch, 1987); B: This paper.

\section{CONCLUSIONS}

The existence of various clay-mineral assemblages and their distribution in the BasqueCantabrian basin are due to the following:

(1) The influence of different source areas that provided differing proportions of kaolinite and smectite; the greater abundance of the former in the southern sector is interpreted as being due to the influence of emerged areas.

(2) A higher degree of diagenesis related to depth and geographical location, increasing from south to north. The diagenetic changes: (a) are related to temperature, subsidence rate and lithology; (b) can be traced by the overall reduction in the quantity of kaolinite and discrete smectite in the rocks and expandable layers in the mixed-layered I-S and by the different values of the Kübler index (Fig. 8); (c) range from shallow diagenesis to anchimetamorphism.

\section{ACKNOWLEDGMENTS}

The authors wish to thank Prof. Kübler of the Institut de Géologie, Université de Neuchâtel, Switzerland, for permitting us the use of his laboratory facilities on several occasions and also for his invaluable advice on our data and interpretations. This work was financed by a research project of the Sociedad de Hidrocarburos de Euskadi (Group EVE) and we owe our gratitude to the director D. Angel Garrote. The study forms part of Research Project PB-870228 (DGICYT) and work carried out by Research Group 4065 of the Junta de Andalucía. This manuscript benefited from the careful revisions of Professor D. R. Peacor and an anonymous referee. 


\section{REFERENCES}

AhN J.H. \& Peacor D.R. (1986) Transmission and analytical electron microscopy of the smectite-illite transition. Clays Clay Miner. 34, 165-179.

Amiot M., Floquet M., Mathey B., Pascal A. \& Salomon J. (1982) Evolution de la marge cantabrique et son arrière-pays iberique au Crétacé. Cuad. Geol. Ibérica, 8, 37-63.

BetHKE C.M. \& AltANER S.P. (1986) Layer-bi-layer mechanism of smectite illitization and application to a new rate law. Clays Clay Miner. 34, 136-145.

BISCAYE P.E. (1965) Mineralogy and sedimentation of recent deep-sea clay in Atlantic Ocean and adjacent seas and oceans. Geol. Soc. Amer. Bull. 76, 803-832.

Biollot G. \& Malod J. (1988) The north and north-west Spanish continental margin: a review. Rev. Soc. Geol. España, 1, 295-316.

BRUCE R.L. \& WARNER M.A. (1986) Relationship between illite-smectite diagenesis and hydrocarbon generation in lower Cretaceous Mowry and Skull Creek shales of the northern Rocky Mountain area. Clays Clay Miner. 34, $390-402$.

Chamley H. (1979) North Atlantic clay sedimentation and paleoenvironment since the late Jurassic. Pp. 342-361 in: Deep Drilling Results in the Atlantic Ocean: Continental Margins and Paleoenvironment. (M. Talwani. W. Hay, \& W.B.F. Ryan, editors), Ser. Am. Geophys. Union.

Chamley H. (1989) Clay Sedimentology pp. 425-524. Springer-Verlag, Berlin.

EBERL D.D. \& SRODON J. (1988) Ostwald ripening and interparticle-diffraction effects for illite crystals. Am. Miner. 73, 1335-1345.

Feuille P. \& Rat P. (1971) Structures et paléogéographies pyrénéo pyrénéo-cantabrique. In: Histoire Structurale du Golfe de Gascogne, 2: V.1. 1.48 Technip.

Freed R.L. \& PEACOR D.R. (1989) Variability in temperature of the smectite/illite reaction in Gulf Coast sediments. Clay Miner. 24, 171-180.

Heling D. (1974) Diagenetic alteration of smectite in argillaceous sediments of the Rhinegraben. Sedimentology. 21, 463-472.

Hower J., Eslinger E., Hower M.E. \& Perry E.A. (1976) Mechanism of burial metamorphism of argillaceous sediments: 1. Mineralogical and chemical evidence. Geol. Soc. Amer. Bull. 87, 725-737.

I.G.M.E. (1987). Contribución de la Exploración Petrolifera al Conocimiento de al Geologia de España. I.G.M.E. Ed. Madrid.

Inoue A., Kohyama N., Kitagawa R. \& Watanabe T. (1987) Chemical and morphological evidence for the conversion of smectite to illite. Clays Clay Miner. 35, 111-120.

Inoue A., Bochet A., Velde B. \& Meunier A. (1989) Convenient technique for estimating smectite layer percentage in randomly interstratified illite/smectite minerals. Clays Clay Miner. 37, 227-234.

Jennings S. \& Thompson G.R. (1986) Diagenesis in Plio-Pleistoene sediments of the Colorado River Delta, southern California. J. Sed. Pet. 56, 88-98.

Jiang W.T., Peacor D.R., Merriman R.J. \& Roberts B. (1990) Transmission and analytical electron microscopic study of mixed-layer illite/smectite formed as an apparent replacement product of diagenetic illite. Clays Clay Miner. 38, 449-468.

Kısch H.J. (1987) Correlation between indicators of very low-grade metamorphism. Pp. 227-300 in: Low Temperature Metamorphism (M. Frey, editor). Blackie, New York.

KısCH H.J. (1990) Recommendations on illite "crystallinity". IGCP Project 294 (VI GM) Working Group, 1-9.

KÜBLER B. (1968) Evaluation quantitative du métamorphisme para la cristallinité de lílite. Bull. Centre Rech. PauSNPA 2, 385-397.

Kübler B., Pittion J.L., Héroux Y., Charollais J. \& Weidmann M. (1979) Sur le pouvoir réflecteur de la vitrinite dans quelques roches du Jura, de la Molasse et des Nappes Préalpines, helvétiques et peniques. Eclogae geol. Helv. 72, 347-373.

Mathey B. (1987) Les flysch du Crétace supérieur des Pyrénes basques (France, Espagne). Mém. Géol. Univ. Dijon, 1-12.

Miller K.G., Fairbanks R.G. \& Mountain G.S. (1987) Tertiary oxygen isotope synthesis, sea level history, and continental margin erosion. Paleoceanography, 2, 1-19.

Pearson M.J. \& Small J.S. (1988) Illite-smectite diagenesis and paleotemperatures in northern North Sea Quaternary to Mesozoic shale sequences. Clay Miner. 23, 109-132.

Ramírez del Pozo J. (1973) Síntesis Geológica de la Provincia de Alava pp. 53-57. Ed. Obra Cultural CAMCV, Vitoria. 
Ramírez del. Pozo J. (1987) Geología del subsuelo en el sector meridional de la Cuenca Vasco-Cantábrica. Geogaceta, 3, 40-44.

Rat P. (1959) Les Pays Crétacés Basco-Cantabriques. Ed. Publ. Univ. Dijon. XVIII.

Reynolds R.C. (1980). Interstratified clay minerals. Pp. 249-304 in: Crystal Structures of Clay Minerals and their $X$-ray Identification (G.W. Brindley \& G. Brown, editors). Mineralogical Society, London.

REYNolds R.C. \& Hower J. (1970) The nature of interlayering in mixed-layer illite-montmorillonite. Clays Clay Miner. 18, 25-36.

Scotchman I.C. (1987) Clay diagenesis in the Kimmeridge Clay Formation. onshore UK, and its relation to organic maturation. Mineral. Mag. 51, 535-551.

Schultz L.G. (1964) Quantitative interpretation of mineralogical composition from X-ray and chemical data for Pierce Shale. U.S. Geol. Surv. Prof. Pap. 391-C.

Singer A. (1984) The paleoclimatic interpretation of clay minerals in sediment. A review. Earth Sci. Rev. 21, 251-293.

Srodon J. (1984) X-ray powder diffraction identification of illitic materials. Clays Clay Miner. 32, 337-349.

Stackelberg U. (1960) Der diapir von Murguia (Nordspanien). PhD thesis, Univ. Bonn, Germany. 